Article

\title{
Unexpectedly Long Lifetime of the Excited State of Benzothiadiazole Derivative and Its Adducts with Lewis Acids
}

\author{
Taisiya S. Sukhikh *D, Radmir M. Khisamov and Sergey N. Konchenko
}

check for updates

Citation: Sukhikh, T.S.; Khisamov, R.M.; Konchenko, S.N. Unexpectedly Long Lifetime of the Excited State of Benzothiadiazole Derivative and Its Adducts with Lewis Acids. Molecules 2021, 26, 2030. https://doi.org/ $10.3390 /$ molecules 26072030

Academic Editor: Fawaz Aldabbagh

Received: 11 March 2021

Accepted: 30 March 2021

Published: 2 April 2021

Publisher's Note: MDPI stays neutral with regard to jurisdictional claims in published maps and institutional affiliations.

Copyright: (c) 2021 by the authors. Licensee MDPI, Basel, Switzerland. This article is an open access article distributed under the terms and conditions of the Creative Commons Attribution (CC BY) license (https:// creativecommons.org/licenses/by/ $4.0 /)$.
Nikolaev Institute of Inorganic Chemistry, Siberian Branch of the Russian Academy of Sciences, 630090 Novosibirsk, Russia; khisamov@niic.nsc.ru (R.M.K.); konch@niic.nsc.ru (S.N.K.)

* Correspondence: sukhikh@niic.nsc.ru

\begin{abstract}
We report a study of photoluminescent properties of 4-bromo-7-(3-pyridylamino)-2,1,3benzothiadiazole $(P y-b t d)$ and its novel Lewis adducts: $(P y H-b t d)_{2}\left(\mathrm{ZnCl}_{4}\right)$ and $\left[\mathrm{Cu}_{2} \mathrm{Cl}_{2}(P y-b t d)_{2}\{P P O\}_{2}\right] \cdot 2 \mathrm{C}_{7} \mathrm{H}_{8}$ $(P P O=$ tetraphenyldiphosphine monoxide), whose crystal structure was determined by $\mathrm{X}$-ray diffraction analysis. $P y$-btd exhibits a lifetime of 9 microseconds indicating its phosphorescent nature, which is rare for purely organic compounds. This phenomenon arises from the heavy atom effect: the presence of a bromine atom in $P y$-btd promotes mixing of the singlet and triplet states to allow efficient singlet-to-triplet intersystem crossing. The Lewis adducts also feature a microsecond lifetime while emitting in a higher energy range than free $P y$ - $b t d$, which opens up the possibility to color-tune luminescence of benzothiadiazole derivatives.
\end{abstract}

Keywords: benzothiadiazole; Lewis acid; photoluminescence; single crystal X-ray diffraction; phosphorescence

\section{Introduction}

Chalcogen-nitrogen heterocycles are actively studied owing to the prospects for their application in electronics [1,2] and biomedicine [3]. 2,1,3-benzothiadiazole (btd) is a common building block for such applications, featuring electron-withdrawing properties [4,5]. Functionalization of $b t d$ with donor substituents provides a way to create luminescent compounds, whose emission occurs owing to the push-pull effect [6-8]. In addition, btd derivatives are prone to secondary bonding interactions such as chalcogen bonding [9] and $\pi-\pi$ stacking, which gives rise to the appearance of various photophysical effects: mechanochromism [10], solvatochromism [11], aggregation-induced emission [12], etc.

2,1,3-benzothiadiazole and, in particular, its amine derivatives are able to bind with Lewis acids owing to the donor $\mathrm{N}$ atoms of the heterocycle and amino group [13]. Further functionalization of the derivatives with donor groups allows one to expand the set of Lewis base centers [14]. For instance, a number of coordination compounds with btd ligands bearing diphenylphosphine [14,15], pyridyl [16,17], triazolyl and pyrazolyl [18] groups were synthesized.

4-bromo-7-(3-pyridylamino)-2,1,3-benzothiadiazole (Py-btd, 1), described recently [19], has a nitrogen atom in the pyridyl substituent, which is known to be a strong Lewis base center. This compound possesses mechanochromic luminescence in solid state, owing to the presence of hydrogen bonds between the amino group and the pyridyl, shortened S $\cdots \mathrm{N}$ contacts and "head-to-tail" $\pi-\pi$ interactions between benzothiadiazole units. Variation of Lewis acids bound with the pyridyl substituent of $P y$-btd would change the electronic structure of the molecule and secondary bonding interactions pattern in the crystal and, consequently, would result in different luminescent properties of a compound. Particularly, $d^{10}$-metal ions, such as $\mathrm{Zn}(\mathrm{II})$ and $\mathrm{Cu}(\mathrm{I})$, are often used to modulate the luminescence of organic derivatives. They benefit for luminescent applications as earth-abundant nonprecious transition elements. Very recently, a number of Zn and Ag coordination compounds with 
different 4,7-dipyridyl-2,1,3-benzothiadiazoles was synthesized, and their photoluminescence was studied [20]. Acting as bitopic ligands, these 4,7-dipyridyl derivatives, however, do not comprise a heavy bromine atom. The latter can promote an efficient intersystem crossing in $P y$-btd and its adducts, which ensures their long emission lifetime.

We have synthesized two novel compounds, $(\mathrm{PyH}-b t d)_{2}\left(\mathrm{ZnCl}_{4}\right)(2)$ and $\left[\mathrm{Cu}_{2} \mathrm{Cl}_{2}(\mathrm{Py}-\right.$ $\left.b t d)_{2}\{P P O\}_{2}\right] \cdot 2 \mathrm{C}_{7} \mathrm{H}_{8}\left(3 \cdot 2 \mathrm{C}_{7} \mathrm{H}_{8}\right)(P P O=$ tetraphenyldiphosphine monoxide $)$ and studied their luminescent properties in comparison with compound 1. All the compounds exhibit microsecond lifetimes of the excited states, which is rarely observed for organic compounds.

\section{Materials and Methods}

\subsection{General}

Elemental analyses were performed on various MICRO cube instrument for $\mathrm{C}, \mathrm{H}, \mathrm{N}$ and S elements. IR-spectra were recorded on a Fourier IR spectrometer FT-801 (Simex) in $\mathrm{KBr}$ pellets. Diffuse-reflectance and photoluminescence spectra were recorded from solid samples on Shimadzu UV-3101 PL and Cary Eclipse spectrometers, respectively. Luminescence decay kinetics were studied on a Cary Eclipse with a Xenon flash lamp ( $80 \mathrm{~Hz}, \sim 2-3 \mu$ s pulse width) using an 80- $\mu$ s delay time and a $50-\mu$ s gate time. For diffusereflectance spectra, samples were prepared by grinding compounds $(0.005 \mathrm{~g})$ with $\mathrm{BaSO}_{4}$ $(0.200 \mathrm{~g})$, which was used as standard. Diffuse-reflectance spectra were recalculated to absorbance spectra by Kubelka-Munk transformation [21].

\subsection{Quantum-Chemical Calculations}

All calculations were performed in Orca 4.2.1 [22]. Geometry of 1 was optimized by DFT with PBE0 functional [23] and a def2-TZVP(-f) basis set in a gaseous state without any constraints. Dispersion interactions were included by D3(BJ) corrections [24]. Vertical excitation energies were calculated by the TD-DFT method with the same DFT functional but including relativistic effects by the ZORA method and using a ZORA-def2-TZVP(-f) basis set. All calculations were accelerated by the RIJCOSX method [25]. Results of vertical excitation energies calculation were analyzed by TheoDORE 2.2 program [26].

\subsection{Syntheses}

Commercially available anhydrous $\mathrm{ZnCl}_{2}$ and $\mathrm{CuCl}$ and other chemicals were used without additional purification. Synthesis and purification of 4-bromo-7-(3-pyridylamino)2,1,3-benzothiadiazole (1) and tetraphenydiphosphinooxide (PPO) were performed according to earlier described methods $[19,27]$.

$(\mathrm{PyH}-b t d)_{2}\left(\mathrm{ZnCl}_{4}\right)(2)$

Amounts of $50.0 \mathrm{mg}(0.162 \mathrm{mmol})$ of 1 and $11.0 \mathrm{mg}(0.0811 \mathrm{mmol})$ of $\mathrm{ZnCl}_{2}$ were dissolved in $\mathrm{CHCl}_{3}(5 \mathrm{~mL})$ by stirring. Yellow precipitate was gradually formed. An amount of $20 \mu \mathrm{L}$ of concentrated $\mathrm{HCl}$ was added and the mixture was stirred for $1 \mathrm{~h}$. Solvent was evaporated under vacuum and precipitate was rinsed with $\mathrm{CHCl}_{3}$ and $n$ hexane and dried under vacuum. Yield $39.8 \mathrm{mg}(60 \%)$. Calculated for $\mathrm{C}_{22} \mathrm{H}_{18} \mathrm{Br}_{2} \mathrm{C}_{14} \mathrm{~N}_{8} \mathrm{~S} 2 \mathrm{Zn}$ (825.57): C 32.0, H 2.2, N 13.6, S 7.8. Measured: C 31.6, H 2.1, N 13.2, S 8.0. IR-spectrum $\left(\mathrm{KBr}, \mathrm{cm}^{-1}\right): 3375(w), 3303(w), 3156(w), 3116(\mathrm{~m}), 3072(\mathrm{~m}), 2921(w), 1627(w), 1550(\mathrm{~s})$, $1484(\mathrm{~m}), 1388(\mathrm{~m}), 1336(\mathrm{~m}), 1245(w), 1110(w), 1069(w), 883(\mathrm{~m}), 785(\mathrm{~m}), 668(\mathrm{~m})$. $\left[\mathrm{Cu}_{2} \mathrm{Cl}_{2}(P y-b t d)_{2}\{P P O\}_{2}\right] \cdot 2 \mathrm{C}_{7} \mathrm{H}_{8}\left(3 \cdot 2 \mathrm{C}_{7} \mathrm{H}_{8}\right)$

Amounts of $20.0 \mathrm{mg}(0.0649 \mathrm{mmol})$ of $1,25.2 \mathrm{mg}(0.0652 \mathrm{mmol})$ PPO and $6.4 \mathrm{mg}$ $(0.0646 \mathrm{mmol})$ of $\mathrm{CuCl}$ were stirred in toluene $(5 \mathrm{~mL})$. The formed precipitate was centrifuged, rinsed with toluene and dried in a vacuum. Yield $38.0 \mathrm{mg}(66 \%)$. Calc. for $\mathrm{C}_{70} \mathrm{H}_{56} \mathrm{Br}_{2} \mathrm{Cl}_{2} \mathrm{Cu}_{2} \mathrm{~N}_{8} \mathrm{O}_{2} \mathrm{P}_{4} \mathrm{~S}_{2} \cdot 2 \mathrm{C}_{7} \mathrm{H}_{8}$ (1771.36): C 57.0, $\mathrm{H}$ 4.1, N 6.3, $\mathrm{S}$ 3.6. Measured: C 57.2, H 4.0, N 6.1, S 3.6. IR-spectrum (KBr, cm $\left.{ }^{-1}\right): 3245(\mathrm{~m}), 3056(\mathrm{~m}), 2926(w), 2852(w), 1635$ (m), $1581(\mathrm{~s}), 1550(\mathrm{~s}), 1481(\mathrm{~s}), 1432(\mathrm{~s}), 1383(\mathrm{~s}), 1302(\mathrm{~m}), 1245(w), 1339(w), 1157(\mathrm{~s}), 1094$ (s), $1027(w), 883(w), 799(\mathrm{~m}), 746(\mathrm{~s}), 695(\mathrm{~s}), 618(w), 559(\mathrm{~m})$. 


\subsection{X-ray Diffraction Analyses}

Single crystal XRD data for compounds 2 and 3 were collected at $150 \mathrm{~K}$ with a Bruker Apex DUO diffractometer equipped with a $4 \mathrm{~K}$ CCD area detector and a graphitemonochromated sealed tube (Mo K $\alpha$ radiation, $\lambda=0.71073 \AA$, mirror optics). Absorption corrections were applied with the use of the SADABS program [28]. The crystal structures were solved using SHELXT [29] and were refined using SHELXL [30] programs with OLEX2 GUI [31]. Atomic displacement parameters for non-hydrogen atoms were refined anisotropically. Hydrogen atoms were refined in the riding model with the exception of those of the amino group in 2, which were refined freely with the DFIX restraint on the corresponding $\mathrm{N}-\mathrm{H}$ bonds. Even relatively large crystals of both 2 and $3 \cdot 2 \mathrm{C}_{7} \mathrm{H}_{8}$ gave poor diffraction. Thus, the data were limited to $2 \theta$ of $48.9^{\circ}$. In the case of $3 \cdot 2 \mathrm{C}_{7} \mathrm{H}_{8}$, crystals tend towards intergrowth, and the structure was refined as a twin. This resulted in a relatively poor quality of the structure with the final R1 of $7.2 \%$.

CCDC 2065425-2065426 contains the supplementary crystallographic data for this paper. These data can be obtained free of charge from the Cambridge Crystallographic Data Centre via www.ccdc.cam.ac.uk/data_request/cif accessed on 30 March 2021.

Powder XRD was carried at $150 \mathrm{~K}$ with a Bruker D8 Venture with a CMOS PHOTON III detector and $\mathrm{I} \mu \mathrm{S} 3.0$ source (CuK $\alpha$ radiation, mirror optics). The samples were prepared by grinding the powders and loading them into $0.5-\mathrm{mm}$ diameter glass capillaries. Diffraction patterns with continuous diffraction arcs were obtained by the $\varphi$-scanning method $\left(360^{\circ}\right)$. To improve the powder orientation statistics, 5 scans were taken at different positions of the goniometer along $\omega$ from $-240^{\circ}$ to $0^{\circ}$. Correction for an external standard (Si) and integration were carried out using the Dioptas program [32]. Experimental and simulated XRD patterns were compared using a Topas Academic version 6 software package [33].

\section{Results and Discussion}

\subsection{Synthesis and Structure}

The reaction between compound $\mathbf{1}$ and $\mathrm{ZnCl}_{2}$ in chloroform results in the salt $(\mathrm{PyH}-$ $b t d)_{2}\left(\mathrm{ZnCl}_{4}\right)(2)$, in which the benzothiadiazole $P y$-btd presents in the protonated form $P y H-b t d^{+}$(Scheme 1, Figure 1). In this reaction, protonation of $P y-b t d$ at the nitrogen atom of the pyridyl group occurs due to the hydrochloric acid present in the solvent. Crystals suitable for XRD analysis were obtained by slow evaporation of a solution in methylene chloride. The target compound 2 in $60 \%$ yield was prepared by adding hydrochloric acid to the reaction mixture in chloroform. Protonated $\mathrm{PyH}-b t d^{+}$in the compound is not coordinated to zinc atom; the latter is surrounded by four chlorides and acts as a counterion. Despite the amino-benzothiadiazole moiety containing three donor $\mathrm{N}$ atoms, they do not coordinate the $\mathrm{ZnCl}_{3}{ }^{-}$fragment (formed from $\mathrm{ZnCl}_{2}$ and one equivalent of $\mathrm{HCl}$ ), and a zwitterionic complex [ $\left.\mathrm{Zn}(\mathrm{PyH}-\mathrm{btd}) \mathrm{Cl}_{3}\right]$ does not form for steric and/or electronic reasons. $\mathrm{N}^{1}$ and $\mathrm{N}^{3}$ atoms of the thiadiazole (for atoms numbering, see Scheme 1) have an interfering steric effect on the $\mathrm{Br}$ and $(\mathrm{N}) \mathrm{H}$ atoms, respectively. The $\mathrm{N}^{4}$ atom of the amino group probably lacks donor strength to coordinate with the $\mathrm{Zn}^{2+}$ ion. The possible chelate coordination of the amino-benzothiadiazole moiety via $\mathrm{N}^{3}$ and $\mathrm{N}^{4}$ atoms is unfavorable, as discussed earlier for archetype 4-amino-2,1,3-benzothiadiazole [34]. Thus, in the case of the $\mathrm{N}^{5}$ site occupied by $\mathrm{H}^{+}$, the $\mathrm{ZnCl}_{3}{ }^{-}$fragment prefers to attach one more $\mathrm{Cl}^{-}$from $\mathrm{HCl}$ to form $\mathrm{ZnCl}_{4}{ }^{2-}$ rather than coordinate to $\mathrm{PyH}-b t d^{+}$, although such complexes with positively charged $\mathrm{N}$-donor ligands are quite common $[35,36]$. 


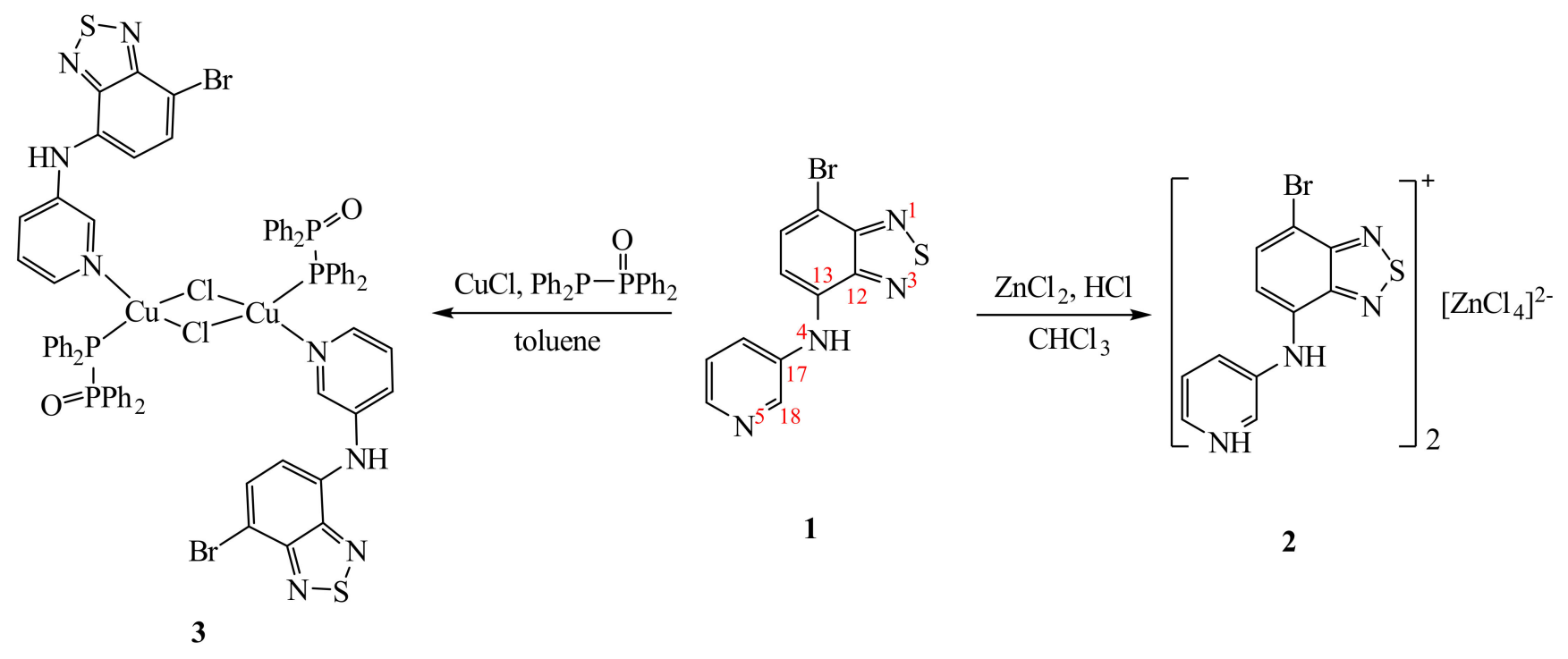

Scheme 1. Synthesis of compounds 2 and $3 \cdot 2 \mathrm{C}_{7} \mathrm{H}_{8}$.

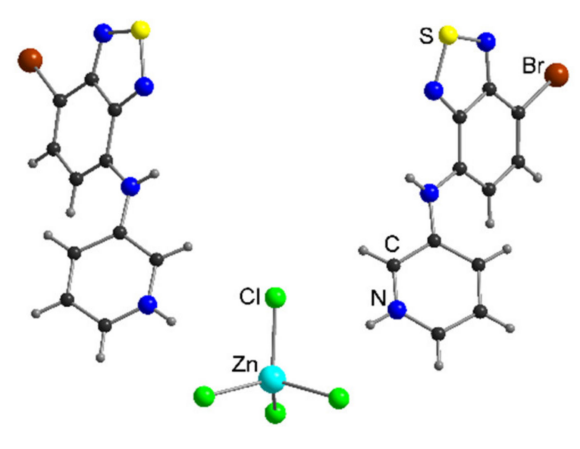

2

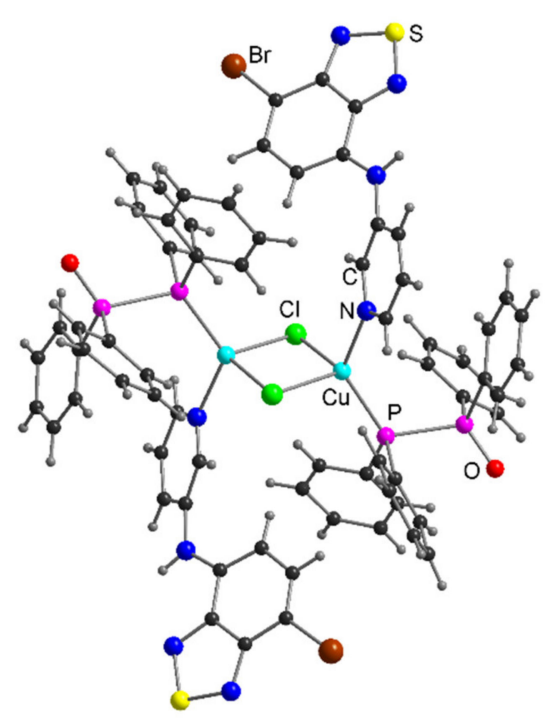

$3 \cdot 2 \mathrm{C}_{7} \mathrm{H}_{8}$

Figure 1. Structure of compounds 2 and $3 \cdot 2 \mathrm{C}_{7} \mathrm{H}_{8}$.

The reaction between $\mathbf{1}$, tetraphenyldiphosphine monoxide (PPO), and copper(I) chloride in toluene gave the heteroligand coordination compound $\left[\mathrm{Cu}_{2} \mathrm{Cl}_{2}(P y-b t d)_{2}\{P P O\}_{2}\right] \cdot 2 \mathrm{C}_{7} \mathrm{H}_{8}$ $\left(3 \cdot 2 \mathrm{C}_{7} \mathrm{H}_{8}\right)$ (Scheme 1$)$. Crystals suitable for XRD analysis were obtained by extraction of the substance with toluene in a two-section ampoule. The compound comprises binuclear complex 3, in which $\mathrm{Cu}$ atoms are bound by bridging $\mathrm{Cl}$ atoms. Two Py-btd ligands are coordinated via the $\mathrm{N}^{5}$ atoms of the pyridyl unit, while the PPO ligand is coordinated via the trivalent phosphorus atom.

Powder diffraction patterns for samples of 2 and $3 \cdot 2 \mathrm{C}_{7} \mathrm{H}_{8}$ (Figures S1 and S2) agree well with those simulated from single crystal XRD data, indicating the phase purity of the compounds.

All bond lengths in compounds 2 and $3 \cdot 2 \mathrm{C}_{7} \mathrm{H}_{8}$ lie in the expected range, while the bonds of the Py-btd unit are close to those in compound 1 [19]. Torsion angles $\mathrm{C}^{12}-\mathrm{C}^{13}-\mathrm{N}^{4}$ $\mathrm{C}^{17}$ for 1-3 are close to $180^{\circ}$ (Table 1 ) owing to the conjugation of the amino group with 
the aromatic system of $b t d$. The geometry of the $P y$-btd unit is similar in $\mathbf{1 , 2}$ and differs from that in $3 \cdot 2 \mathrm{C}_{7} \mathrm{H}_{8}$ mainly by the torsion $\mathrm{C}^{13}-\mathrm{N}^{4}-\mathrm{C}^{17}-\mathrm{C}^{18}$ angle; however, the tilt of the pyridyl group relative to the amino-benzothiadiazole is similar in all the structures up to a change of place of $\mathrm{N}^{5}$ and $\mathrm{C}^{20}$ atoms.

Table 1. Dihedral angles (deg.) and shortened intermolecular contacts ( $\AA$ ) for the 4-bromo-7-(3pyridylamino)-2,1,3-benzothiadiazole ( $P y$-btd) unit in compounds $\mathbf{1}$ [19], 2 and $3 \cdot 2 \mathrm{C}_{7} \mathrm{H}_{8}$. For atom numbering, see Scheme 1.

\begin{tabular}{ccccc}
\hline Compound & $\mathrm{C}^{12}-\mathrm{C}^{13}-\mathrm{N}^{4}-\mathrm{C}^{17}$ & $\mathrm{C}^{13}-\mathrm{N}^{4}-\mathrm{C}^{17}-\mathrm{C}^{18}$ & $\mathbf{S} \cdots A^{*}$ & $\begin{array}{c}\mathrm{C}_{6} \text { Centroid- } \mathrm{C}_{2} \mathbf{N}_{2} \mathrm{~S}, \\
\text { Centroid }\end{array}$ \\
\hline $\mathbf{1}$ & 180.0 & 149.4 & 2.99 & 3.58 \\
$\mathbf{2}$ & $158.1,163.0$ & $153.4,155.3$ & 3.27 & 3.57 \\
$\mathbf{3} \cdot 2 \mathrm{C}_{7} \mathrm{H}_{8}$ & $168.6,174.0$ & $30.9,36.5$ & $3.25,3.43$ & $3.55,3.59 *$ \\
\hline
\end{tabular}

* For 1 and $3 \cdot 2 \mathrm{C}_{7} \mathrm{H}_{8}, A=\mathrm{N}$; for $2, A=\mathrm{Cl}$. For $3 \cdot 2 \mathrm{C}_{7} \mathrm{H}_{8}, \mathrm{C}_{6}$ moiety belongs to the phenyl group of the tetraphenyldiphosphine monoxide $(P P O)$ ligand.

In crystal 2, $P y H-b t d^{+}$cations are engaged in "head-to-tail" $\pi-\pi$ stacking in tetramers, which, in turn, form a parquet pattern (Figure 2). In addition, the structure reveals intermolecular hydrogen bonds $\mathrm{N}^{4} \mathrm{H} \cdots \mathrm{Cl}$ and shortened contacts $\mathrm{S} \cdots \mathrm{Cl}$ and $\mathrm{Br} \cdots \mathrm{Br}$. The structure $3 \cdot 2 \mathrm{C}_{7} \mathrm{H}_{8}$ reveals $\pi-\pi$ interaction between the $b t d$ unit and one of phenyl groups, intermolecular hydrogen bonds $\mathrm{N}^{4} \mathrm{H} \cdots \mathrm{O}$ and shortened contacts $\mathrm{S} \cdots \mathrm{N}$ (Figure 3 ). In $3 \cdot 2 \mathrm{C}_{7} \mathrm{H}_{8}$, no specific interactions with $\mathrm{Br}$ atoms were found.

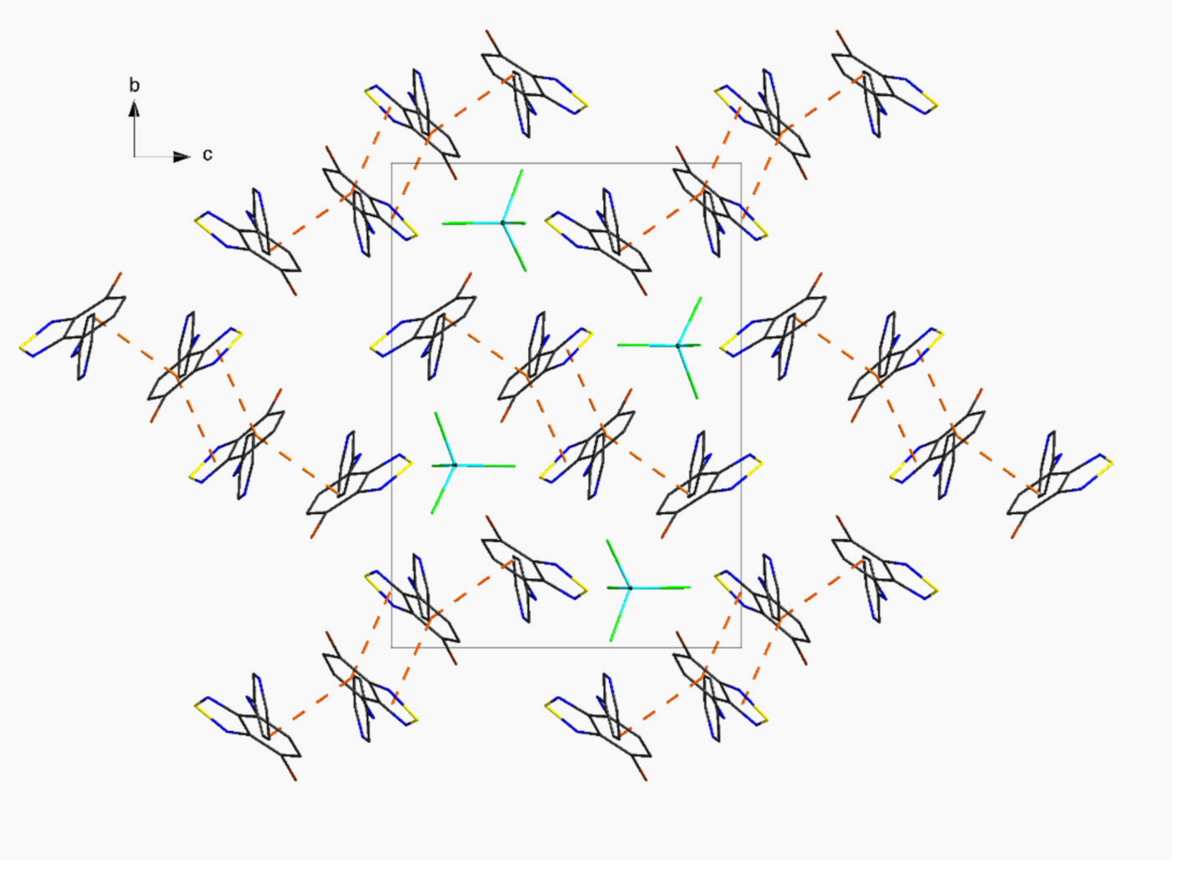

(a)

Figure 2. Cont. 


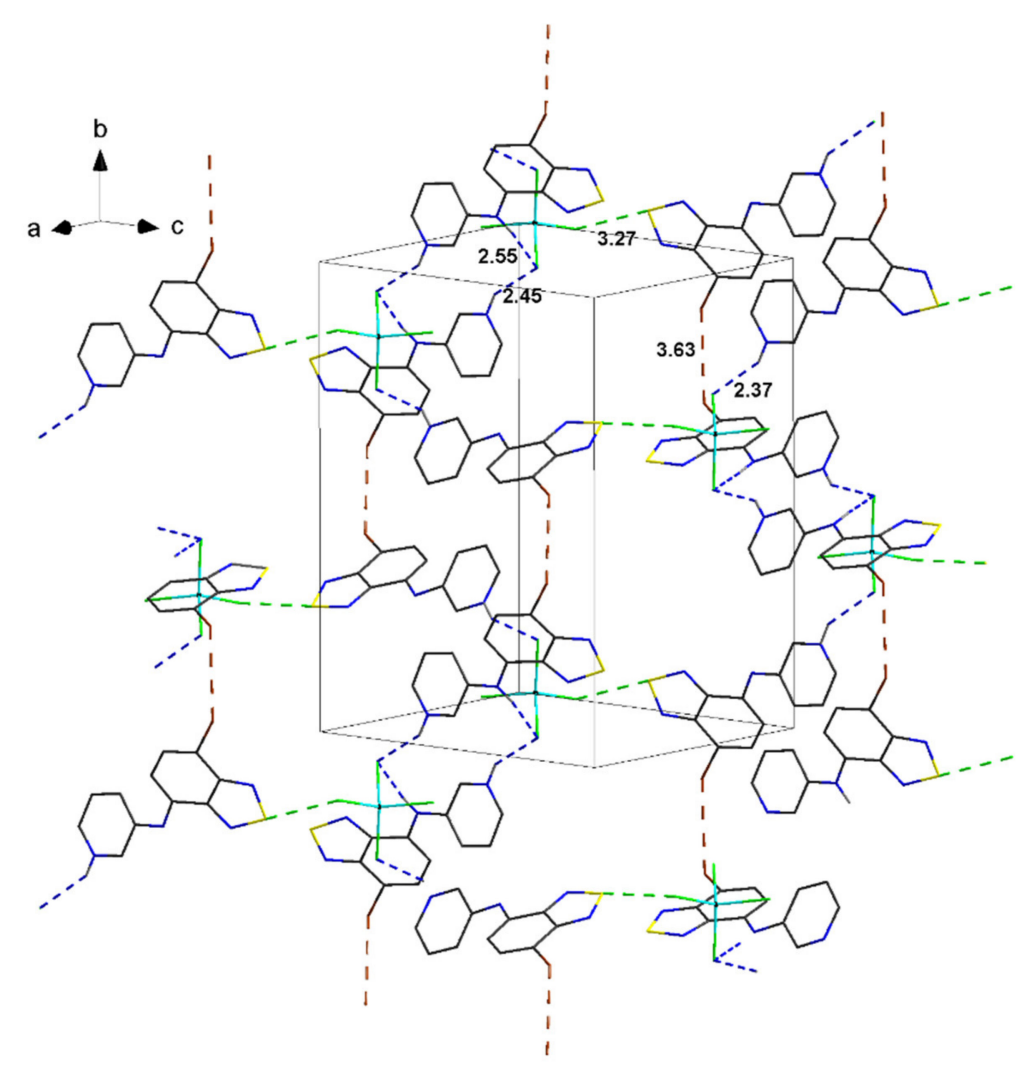

(b)

Figure 2. Crystal packing of 2 showing (a) $\pi-\pi$ interactions (orange dashed lines) and (b) $\mathrm{Br} \cdots \mathrm{Br}$ (brown dashed lines), S $\cdots \mathrm{Cl}$ contacts (green dashed lines) and $\mathrm{N}^{4} \mathrm{H} \cdots \mathrm{Cl}$ hydrogen bonds (blue dashed lines). Hydrogens except those participating in the hydrogen bonds are not shown.

\subsection{Photophysical Properties}

For compounds 2 and $3 \cdot 2 \mathrm{C}_{7} \mathrm{H}_{8}$ in the solid state (polycrystalline samples for luminescence studies and a mixture with $\mathrm{BaSO}_{4}$ for UV-vis), the UV-vis (Figure 4) and photoluminescence (Figure 5) spectra were measured. Compared to compound $\mathbf{1}$ [19], the shape of UV-vis spectra for $\mathbf{2}$ and $3 \cdot 2 \mathrm{C}_{7} \mathrm{H}_{8}$ differs slightly (Table 2). They are characterized by a broad high-energy band at ca. $260-320 \mathrm{~nm}$ and a low-energy band at ca. $450 \mathrm{~nm}$.

According to the TD-DFT calculation on the ZORA-PBE0/def2-TZVP(- $\mathrm{f}$ ) theory level (Table 3, Figure 6), the lowest energy absorption band of $\mathbf{1}$ at $455 \mathrm{~nm}$ corresponds mainly to a transition between the HOMO and LUMO, with intermediate character between charge transfer from pyridyl and $\mathrm{Br}$ to btd fragments and local excitation (Figure 6), as indicated by charge transfer (CT) number (Table 3). However, such transitions in related compounds are often referred to as charge transfer [37-39]. Multiple bands at ca. 270-300 correspond to a combination of promotions from HOMO, HOMO-1, and HOMO-2 to LUMO, LUMO+1 and LUMO+2.

Table 2. Photophysical properties of compounds $\mathbf{1}$ [19], 2 and $3 \cdot 2 \mathrm{C}_{7} \mathrm{H}_{8}$.

\begin{tabular}{cccc}
\hline Compound & $\boldsymbol{\lambda}_{\mathrm{Em}}, \mathbf{n m}$ & $\boldsymbol{\lambda}_{\mathrm{Em}}, \mathbf{n m}$ & $\boldsymbol{\tau}, \boldsymbol{\mu s}$ \\
\hline $\mathbf{1}$ & $265-320(\mathrm{br}), 455$ & 600 & 9 \\
$\mathbf{2}$ & $255-315(\mathrm{br}), 445$ & 565 & 18 \\
$3 \cdot 2 \mathrm{C}_{7} \mathrm{H}_{8}$ & $278-320(\mathrm{br}), 470$ & 552 & 9 \\
\hline
\end{tabular}




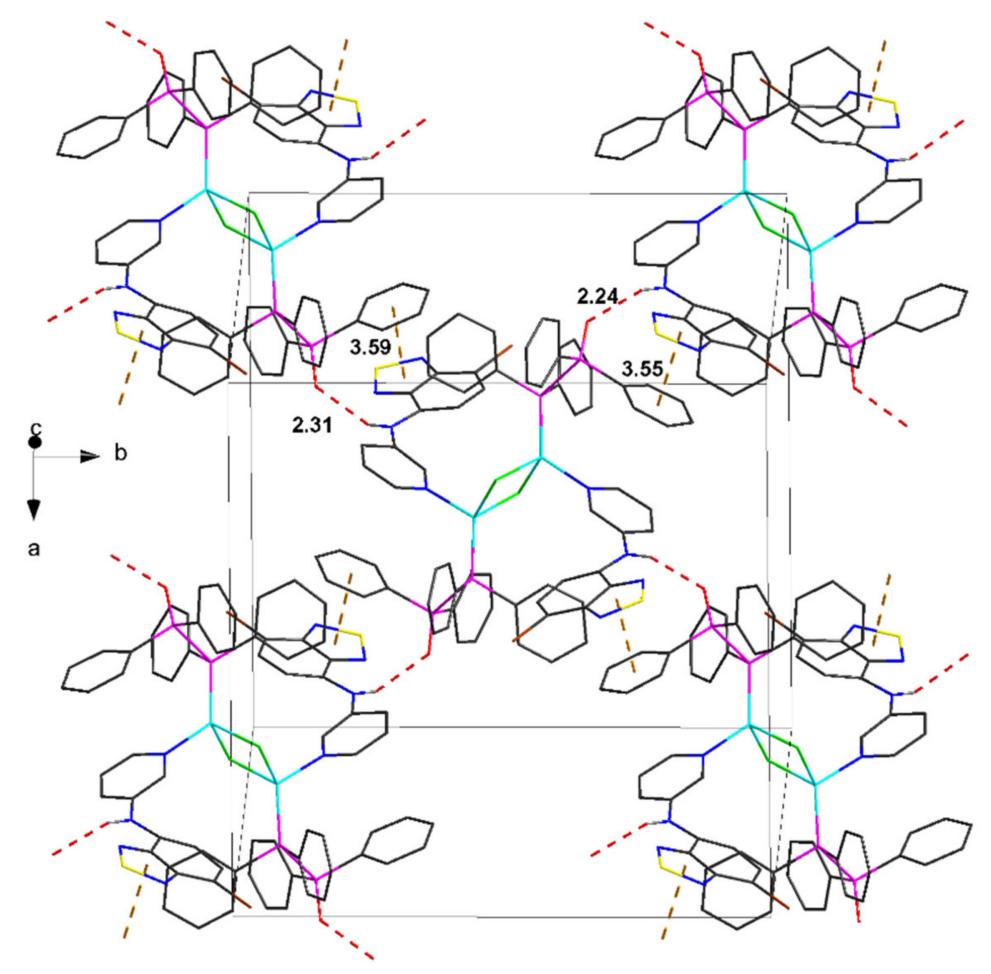

(a)

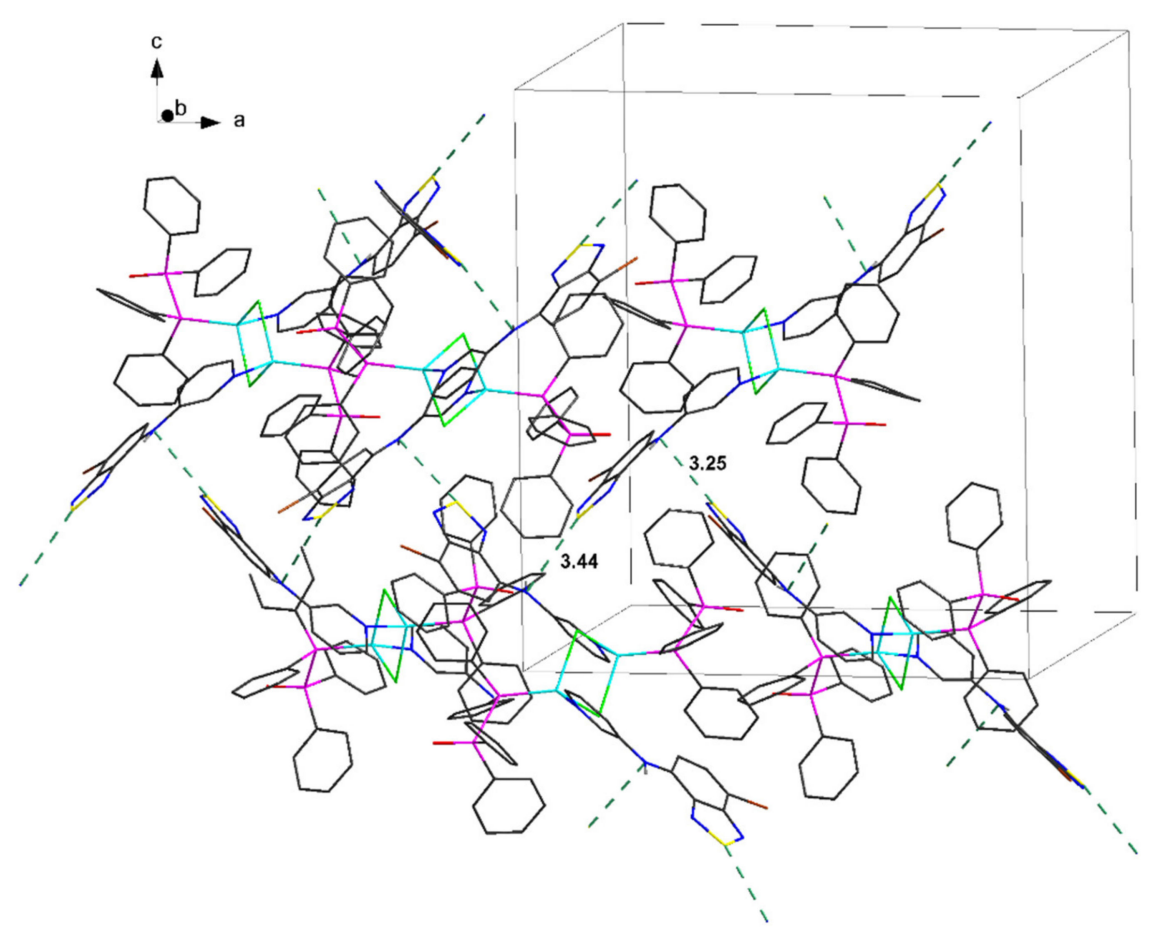

(b)

Figure 3. Crystal packing of $3 \cdot 2 \mathrm{C}_{7} \mathrm{H}_{8}$ showing (a) $\pi-\pi$ interactions (orange dashed lines) and $\mathrm{N}^{4} \mathrm{H} \cdots \mathrm{O}$ hydrogen bonds (red dashed lines) and (b) S $\cdots \mathrm{N}^{4}$ contacts (green dashed lines). Toluene molecules and hydrogens except those participating in the hydrogen bonds are not shown. 


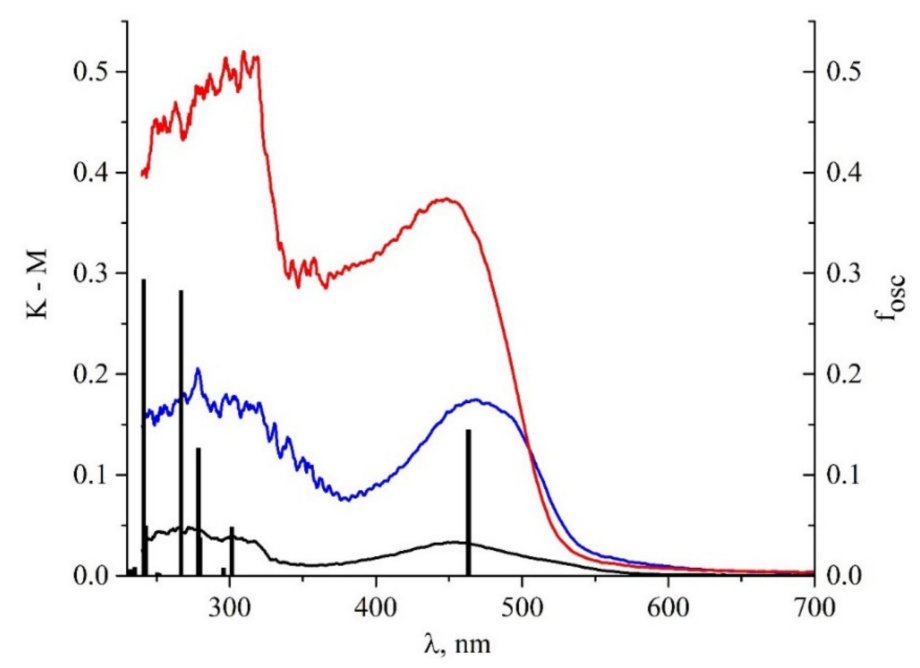

Figure 4. UV-Vis spectra of the solid samples of $\mathbf{1}$ (black) [19], 2 (red), and $3 \cdot 2 \mathrm{C}_{7} \mathrm{H}_{8}$ (blue) mixed with $\mathrm{BaSO}_{4}$, presented in the form of Kubelka-Munk (K-M) functions; the intensities are recalculated to 0.005 mole fraction of the compounds. Black vertical lines represent calculated TD-DFT transitions (ZORA-PBE0/def2-TZVP(-f)) for 1.

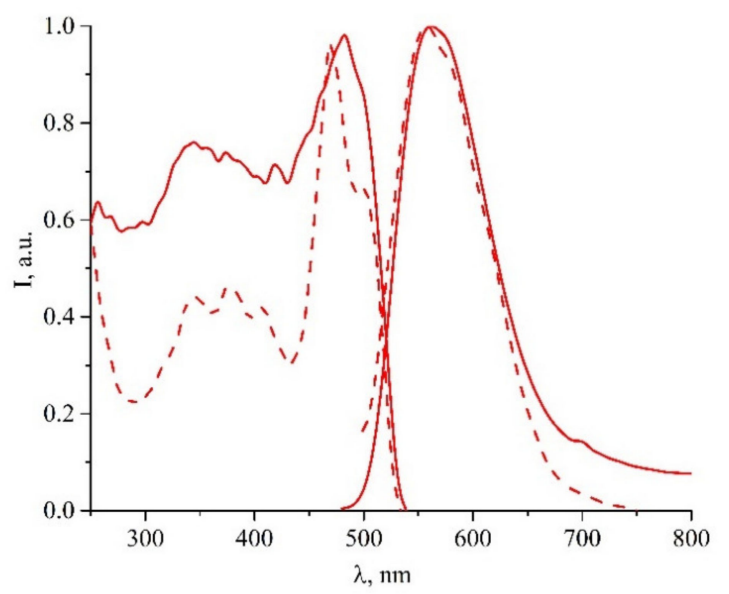

Sample 2

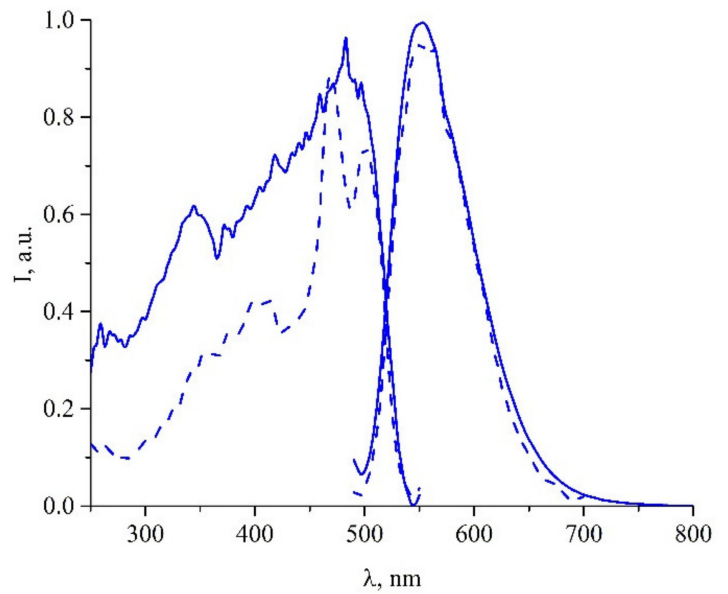

Sample 3

Figure 5. Normalized steady-state (solid lines) and delayed (100 $\mu \mathrm{s})$ excitation and emission spectra of solid samples $2,3$.

Table 3. Main transitions in Py-btd molecule. f-oscillator strength, $\mathrm{H}-\mathrm{HOMO}, \mathrm{L}-\mathrm{LUMO}, \mathrm{CT}-$ charge transfer number *

\begin{tabular}{cccccc}
\hline State & $\boldsymbol{\lambda}, \mathbf{n m}$ & $\mathbf{f}$ & Transition & Contribution & $\mathbf{C T}$ \\
\hline 1 & 463.2 & 0.1446 & $\mathrm{H} \rightarrow \mathrm{L}$ & 0.9869 & 0.503 \\
2 & 301.4 & 0.0481 & $\mathrm{H} \rightarrow \mathrm{L}+1$ & 0.9400 & 0.700 \\
3 & 295.7 & 0.0075 & $\mathrm{H}-1 \rightarrow \mathrm{L}$ & 0.9555 & 0.728 \\
4 & 279.5 & 0.0379 & $\mathrm{H}-2 \rightarrow \mathrm{L}$ & 0.6953 & 0.838 \\
5 & 278.5 & 0.1268 & $\mathrm{H} \rightarrow \mathrm{L}+2$ & 0.1774 & 0.385 \\
6 & 269.2 & 0.0002 & $\mathrm{H}-1 \rightarrow \mathrm{L}$ & 0.95548 & 0.573 \\
& & & $\mathrm{H} \rightarrow \mathrm{L}+2$ & 0.6953 & \\
7 & 266.7 & 0.2827 & $\mathrm{H}-3 \rightarrow \mathrm{L} \rightarrow \mathrm{L}+2$ & 0.1774 & 0.497742 \\
\end{tabular}

${ }^{*}$ CT calculated by Theodore 2.2 program [26]. For charge transfer process, the CT number is close to 1.0, for local excitations it is close to 0 . 


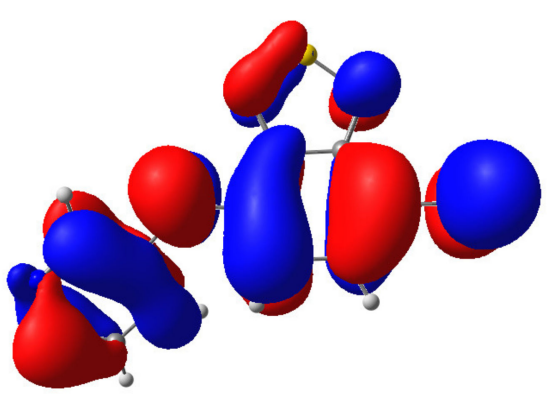

(HOMO)

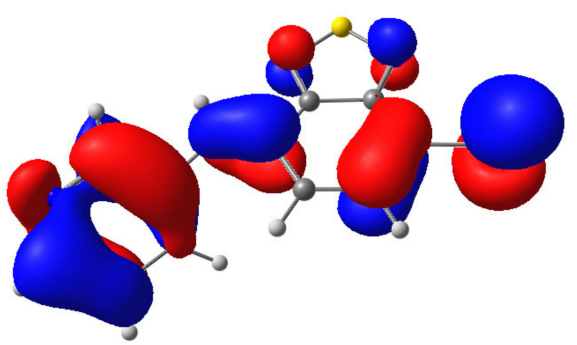

(HOMO-1)

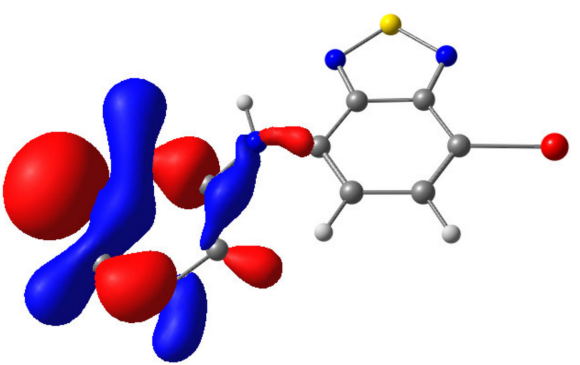

(HOMO-2)

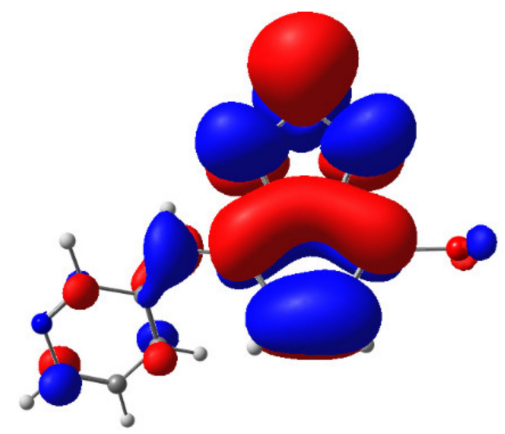

(LUMO)

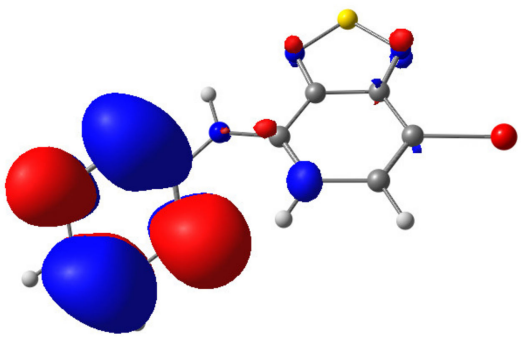

(LUMO+1)

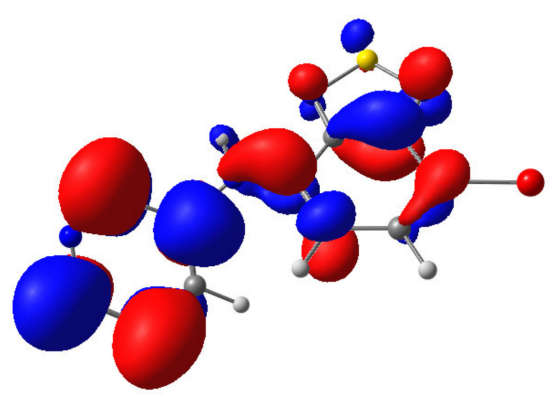

(LUMO+2)

Figure 6. Frontier orbitals of $\mathbf{1}$ based on ZORA-PBE0/def2-TZVP(-f) calculation (isovalue $=0.02$ a.u.).

Upon UV- or blue light irradiation, the compounds emit light in the visible region. Emission maximum hypsochromically shifts by 35 and $48 \mathrm{~nm}$ on going from $\mathbf{1}$ to 2 and to $3 \cdot 2 \mathrm{C}_{7} \mathrm{H}_{8}$, respectively. Unexpectedly, compound $\mathbf{1}$ exhibits a microsecond order of luminescence lifetime at room temperature, which is not typical for purely organic substances $[40,41]$ and indicates a triplet origin of the excited state. Delayed luminescence spectra of all compounds overlap well with the steady-state spectra (Figure 5), indicating that the transition occurs from one emitting species. The relatively long lifetime, similar for 1-3, apparently originates from the heavy atom effect. The presence of a heavy atom, e.g., bromine, in the compounds promotes the intersystem crossing (ISC) process that occurs between the excited singlet and the triplet excited state [42,43]. To the best of our knowledge, only two works have been reported on purely organic phosphorescent Br-substituted 2,1,3-benzothiadiazoles [44,45], and a few more works have been devoted to organic non-bromine 2,1,3-benzothiadiazoles showing microsecond lifetimes [46-48]. Metal-containing phosphorescent benzothiadiazoles are more abundant, but examples of metals are predominantly represented by precious $\mathrm{Pt}(\mathrm{II})$ [49-51], $\mathrm{Au}(\mathrm{III})$ [52], $\mathrm{Au}(\mathrm{I})$ [53], $\operatorname{Ir}(\mathrm{III})[54,55]$ and $\mathrm{Ru}(\mathrm{II})[56]$.

\section{Conclusions}

To sum up, we modulated optical features of 4-bromo-7-(3-pyridylamino)-2,1,3benzothiadiazole $(P y-b t d, 1)$ by introducing Lewis acids, viz $\mathrm{H}^{+}$and $\mathrm{Cu}^{+}$. The corre- 
sponding novel compounds $(P y H-b t d)_{2}\left(\mathrm{ZnCl}_{4}\right)(2)$ and $\left[\mathrm{Cu}_{2} \mathrm{Cl}_{2}(P y-b t d)_{2}\{P P O\}_{2}\right] \cdot 2 \mathrm{C}_{7} \mathrm{H}_{8}$ $\left(3 \cdot 2 \mathrm{C}_{7} \mathrm{H}_{8} ; P P O=\right.$ tetraphenyldiphosphine monoxide $)$ were characterized by single crystal $\mathrm{X}$-ray diffraction analysis and other physical-chemical methods. Unexpectedly, free Py-btd exhibits a microsecond order of luminescence lifetime at room temperature, which is not typical for purely organic substances and indicates a triplet origin of the excited state. The efficient singlet-to-triplet intersystem crossing, essential for a long-lifetime emission, is governed by the heavy atom effect. In our case, the heavy atom is bromine. Both Lewis adducts 2 and $3 \cdot 2 \mathrm{C}_{7} \mathrm{H}_{8}$ also possess a microsecond lifetime. As compared to free $P y$-btd, they reveal a noticeable hypsochromic shift of the emission band (with the energy difference of ca. 1000 and $1450 \mathrm{~cm}^{-1}$ for 2 and $3 \cdot 2 \mathrm{C}_{7} \mathrm{H}_{8}$, respectively), associated with the electronic influence of the Lewis acids. This motivates further design of phosphorescent benzothiadiazoles and their Lewis acid adducts.

Supplementary Materials: The following are available online. Table S1: Crystal data and struc-ture refinement for 2-3. Figures S1 and S2: experimental and simulated powder diffraction pat-terns for 2-3.

Author Contributions: Conceptualization, S.N.K.; funding acquisition, T.S.S.; investigation, R.M.K. and T.S.S.; methodology, T.S.S.; supervision, S.N.K.; visualization; R.M.K. and T.S.S.; writing-original draft, R.M.K.; writing - review and editing: S.N.K. and T.S.S. All authors have read and agreed to the published version of the manuscript.

Funding: This research was funded by the Russian Science Foundation (project no. 19-73-00030).

Institutional Review Board Statement: Not applicable.

Informed Consent Statement: Not applicable.

Data Availability Statement: Not applicable.

Acknowledgments: We are grateful to Siberian Supercomputer Center of Institute of Computational Mathematics and Mathematical Geophysics for computational capability and thank the technical staff of the Institute for the assistance. We also thank XRD and Analytical Facility of NIIC SB RAS for the data collection.

Conflicts of Interest: The authors declare no conflict of interest. The funders had no role in the design of the study; in the collection, analyses, or interpretation of data; in the writing of the manuscript, or in the decision to publish the results.

Sample Availability: Samples of compounds 1-3 are available from the authors.

\section{References}

1. Godfroy, M.; Liotier, J.; Mwalukuku, V.M.; Joly, D.; Huaulmé, Q.; Cabau, L.; Aumaitre, C.; Kervella, Y.; Narbey, S.; Oswald, F.; et al. Benzothiadiazole-based photosensitizers for efficient and stable dye-sensitized solar cells and 8.7\% efficiency semi-transparent mini-modules. Sustain. Energy Fuels 2021, 5, 144-153. [CrossRef]

2. Li, Y.; Qian, Q.; Ling, S.; Fan, T.; Zhang, C.; Zhu, X.; Zhang, Q.; Zhang, Y.; Zhang, J.; Yu, S.; et al. A benzothiadiazole-containing $\pi$-conjugated small molecule as promising element for nonvolatile multilevel resistive memory device. J. Solid State Chem. 2021, 294, 121850. [CrossRef]

3. Neto, B.A.D.; Carvalho, P.H.P.R.; Correa, J.R. Benzothiadiazole Derivatives as Fluorescence Imaging Probes: Beyond Classical Scaffolds. Acc. Chem. Res. 2015, 48, 1560-1569. [CrossRef]

4. Pritchina, E.A.; Gritsan, N.P.; Rakitin, O.A.; Zibarev, A.V. 2,1,3-Benzochalcogenadiazoles: Regularities and peculiarities over a whole chalcogen pentad O, S, Se, Te and Po. Targets Heterocycl. Syst. 2019, 23, 143-154. [CrossRef]

5. Rakitin, O.A. Fused 1,2,5-thia- and 1,2,5-selenadiazoles: Synthesis and application in materials chemistry. Tetrahedron Lett. 2020, 61, 152230. [CrossRef]

6. Martín, R.; Prieto, P.; Carrillo, J.R.; Rodríguez, A.M.; De Cozar, A.; Boj, P.G.; Díaz-García, M.A.; Ramírez, M.G. Design, synthesis and amplified spontaneous emission of 1,2,5-benzothiadiazole derivatives. J. Mater. Chem. C 2019, 7, 9996-10007. [CrossRef]

7. Wang, Z.; Wang, Z.; Lu, P.; Wang, Y. Preparation and Photoluminescent Properties of Three 5-Amino Benzothiadiazoles (5amBTDs). Chem. Asian J. 2020, 15, 3519-3526. [CrossRef] [PubMed]

8. Korshunov, V.M.; Chmovzh, T.N.; Golovanov, I.S.; Knyazeva, E.A.; Mikhalchenko, L.V.; Saifutyarov, R.S.; Avetisov, I.C.; Woollins, J.D.; Taydakov, I.V.; Rakitin, O.A. Candle light-style OLEDs with benzochalcogenadiazoles cores. Dye. Pigment. 2021, $185,108917$. [CrossRef] 
9. Chulanova, E.A.; Radiush, E.A.; Shundrina, I.K.; Bagryanskaya, I.Y.; Semenov, N.A.; Beckmann, J.; Gritsan, N.P.; Zibarev, A.V. Lewis Ambiphilicity of 1,2,5-Chalcogenadiazoles for Crystal Engineering: Complexes with Crown Ethers. Cryst. Growth Des. 2020, 20, 5868-5879. [CrossRef]

10. Gautam, P.; Maragani, R.; Mobin, S.M.; Misra, R. Reversible mechanochromism in dipyridylamine-substituted unsymmetrical benzothiadiazoles. RSC Adv. 2014, 4, 52526-52529. [CrossRef]

11. Shimogawa, H.; Yoshikawa, O.; Aramaki, Y.; Murata, M.; Wakamiya, A.; Murata, Y. 4,7-Bis[3-(dimesitylboryl)thien-2yl]benzothiadiazole: Solvato-, Thermo-, and Mechanochromism Based on the Reversible Formation of an Intramolecular B-N Bond. Chem. A Eur. J. 2017, 23, 3784-3791. [CrossRef] [PubMed]

12. Pazini, A.; Maqueira, L.; Santos, F.D.S.; Barreto, A.R.J.; Carvalho, R.D.S.; Valente, F.M.; Back, D.; Aucélio, R.Q.; Cremona, M.; Rodembusch, F.S.; et al. Designing highly luminescent aryloxy-benzothiadiazole derivatives with aggregation-induced enhanced emission. Dye. Pigment. 2020, 178, 108377. [CrossRef]

13. Sukhikh, T.S.; Ogienko, D.S.; Bashirov, D.A.; Konchenkoa, S.N. Luminescent complexes of 2,1,3-benzothiadiazole derivatives. Russ. Chem. Bull. 2019, 68, 651-661. [CrossRef]

14. Sukhikh, T.S.; Khisamov, R.M.; Bashirov, D.A.; Komarov, V.Y.; Molokeev, M.S.; Ryadun, A.A.; Benassi, E.; Konchenko, S.N. Tuning of the Coordination and Emission Properties of 4-Amino-2,1,3-Benzothiadiazole by Introduction of Diphenylphosphine Group. Cryst. Growth Des. 2020, 20, 5796-5807. [CrossRef]

15. Khisamov, R.; Sukhikh, T.; Bashirov, D.; Ryadun, A.; Konchenko, S. Structural and Photophysical Properties of 2,1,3Benzothiadiazole-Based Phosph(III)azane and Its Complexes. Molecules 2020, 25, 2428. [CrossRef]

16. Jiang, Q.-J.; Lin, J.-Y.; Hu, Z.-J.; Hsiao, V.K.S.; Chung, M.-Y.; Wu, J.-Y. Luminescent Zinc(II) Coordination Polymers of Bis(pyridin4-yl)benzothiadiazole and Aromatic Polycarboxylates for Highly Selective Detection of Fe(III) and High-Valent Oxyanions. Cryst. Growth Des. 2021. [CrossRef]

17. Shen, K.; Ju, Z.; Qin, L.; Wang, T.; Zheng, H. Two stable 3D porous metal-organic frameworks with high selectivity for detection of PA and metal ions. Dyes Pigm. 2017, 136, 515-521. [CrossRef]

18. Qiu, C.-Q.; Li, L.-Q.; Yao, S.-L.; Liu, S.-J.; Xu, H.; Zheng, T.-F. Two benzothiadiazole-based compounds as multifunctional fluorescent sensors for detection of organic amines and anions. Polyhedron 2021, 199, 115100. [CrossRef]

19. Sukhikh, T.S.; Khisamov, R.M.; Bashirov, D.A.; Kovtunova, L.M.; Kuratieva, N.V.; Konchenko, S.N. Substituent Effect on the Structure and Photophysical Properties of Phenylamino- and Pyridylamino-2,1,3-Benzothiadiazoles. J. Struct. Chem. 2019, 60, 1670-1680. [CrossRef]

20. Mocanu, T.; Plyuta, N.; Cauchy, T.; Andruh, M.; Avarvari, N. Dimensionality Control in Crystalline Zinc(II) and Silver(I) Complexes with Ditopic Benzothiadiazole-Dipyridine Ligands. Chemistry 2021, 3, 269-287. [CrossRef]

21. Kubelka, P. New Contributions to the Optics of Intensely Light-Scattering Materials Part I. J. Opt. Soc. Am. 1948, 38, 448. [CrossRef] [PubMed]

22. Neese, F. Software update: The ORCA program system, version 4.0. Wiley Interdiscip. Rev. Comput. Mol. Sci. 2018, 8, 8. [CrossRef]

23. Adamo, C.; Barone, V. Toward reliable density functional methods without adjustable parameters: The PBE0 model. J. Chem. Phys. 1999, 110, 6158-6170. [CrossRef]

24. Grimme, S.; Ehrlich, S.; Goerigk, L. Effect of the damping function in dispersion corrected density functional theory. J. Comput. Chem. 2011, 32, 1456-1465. [CrossRef]

25. Neese, F.; Wennmohs, F.; Hansen, A.; Becker, U. Efficient, approximate and parallel Hartree-Fock and hybrid DFT calculations. A 'chain-of-spheres' algorithm for the Hartree-Fock exchange. Chem. Phys. 2009, 356, 98-109. [CrossRef]

26. Plasser, F. TheoDORE: A toolbox for a detailed and automated analysis of electronic excited state computations. J. Chem. Phys. 2020, 152, 084108. [CrossRef]

27. McKechnie, J.; Payne, D.S.; Sim, W. Tetraphenyldiphosphine monoxide. J. Chem. Soc. 1965, 3500-3501. [CrossRef]

28. Bruker Apex3 Software Suite: Apex3, SADABS-2016/2 and SAINT, Version 2017.3-0; Bruker AXS Inc.: Madison, WI, USA, 2017.

29. Sheldrick, G.M. SHELXT- Integrated space-group and crystal-structure determination. Acta Cryst. 2015, 71, 3-8. [CrossRef]

30. Sheldrick, G.M. Crystal structure refinement with SHELXL. Acta Cryst. 2015, 71, 3-8. [CrossRef]

31. Dolomanov, O.V.; Bourhis, L.J.; Gildea, R.J.; Howard, J.A.K.; Puschmann, H. OLEX2: A complete structure solution, refinement and analysis program. J. Appl. Crystallogr. 2009, 42, 339-341. [CrossRef]

32. Prescher, C.; Prakapenka, V.B. DIOPTAS: A program for reduction of two-dimensional X-ray diffraction data and data exploration. High Press. Res. 2015, 35, 223-230. [CrossRef]

33. Coelho, A.A. TOPASandTOPAS-Academic: An optimization program integrating computer algebra and crystallographic objects written in C++. J. Appl. Crystallogr. 2018, 51, 210-218. [CrossRef]

34. Sukhikh, T.; Komarov, V.; Konchenko, S.; Benassi, E. The hows and whys of peculiar coordination of 4-amino-2,1,3benzothiadiazole. Polyhedron 2018, 139, 33-43. [CrossRef]

35. Zehra, S.; Tabassum, S.; Al-Lohedan, H.A.; Arjmand, F. A zwitterionic Zn(II) benzothiazole nanohybrid conjugate as hydrolytic DNA cleavage agent. Inorg. Chem. Commun. 2018, 93, 69-72. [CrossRef]

36. Pons, R.; Ibáñez, C.; Buades, A.B.; Franconetti, A.; Garcia-Raso, A.; Fiol, J.J.; Terrón, A.; Molins, E.; Frontera, A. Synthesis, X-ray characterization and density functional theory studies of N 6 -benzyl-N 6 -methyladenine-M(II) complexes (M = Zn, Cd): The prominent role of $\pi-\pi, \mathrm{C}-\mathrm{H} \cdots \pi$ and anion $-\pi$ interactions. Appl. Organomet. Chem. 2019, 33, e4906. [CrossRef] 
37. Medeiros, G.A.; Correa, J.R.; De Andrade, L.P.; Lopes, T.O.; De Oliveira, H.C.; Diniz, A.B.; Menezes, G.B.; Rodrigues, M.O.; Neto, B.A. A benzothiadiazole-quinoline hybrid sensor for specific bioimaging and surgery procedures in mice. Sens. Actuators $B$ Chem. 2021, 328, 128998. [CrossRef]

38. Baranov, D.S.; Krivenko, O.L.; Kazantsev, M.S.; Nevostruev, D.A.; Kobeleva, E.S.; Zinoviev, V.A.; Dmitriev, A.A.; Gritsan, N.P.; Kulik, L.V. Synthesis of 2,2'-[2,2'-(arenediyl)bis(anthra[2,3-b]thiophene-5,10-diylidene)]tetrapropanedinitriles and their performance as non-fullerene acceptors in organic photovoltaics. Synth. Met. 2019, 255, 116097. [CrossRef]

39. Passos, S.T.; Souza, G.C.; Brandão, D.C.; Machado, D.F.; Grisolia, C.K.; Correia, J.R.; da Silva, W.A.; Neto, B.A. Plasma membrane staining with fluorescent hybrid benzothiadiazole and coumarin derivatives: Tuning the cellular selection by molecular design. Dye. Pigment. 2021, 186, 109005. [CrossRef]

40. Jia, W.; Wang, Q.; Shi, H.; An, Z.; Huang, W. Manipulating the Ultralong Organic Phosphorescence of Small Molecular Crystals. Chem. A Eur. J. 2019, 26, 4437-4448. [CrossRef]

41. Zhan, G.; Liu, Z.; Bian, Z.; Huang, C. Recent Advances in Organic Light-Emitting Diodes Based on Pure Organic Room Temperature Phosphorescence Materials. Front. Chem. 2019, 7, 305. [CrossRef]

42. Li, Q.; Tang, Y.; Hu, W.; Li, Z. Fluorescence of Nonaromatic Organic Systems and Room Temperature Phosphorescence of Organic Luminogens: The Intrinsic Principle and Recent Progress. Small 2018, 14, e1801560. [CrossRef] [PubMed]

43. Liu, C.; Hamzehpoor, E.; Sakai-Otsuka, Y.; Jadhav, T.; Perepichka, D.F. A Pure-Red Doublet Emission with 90 \% Quantum Yield: Stable, Colorless, Iodinated Triphenylmethane Solid. Angew. Chem. 2020, 132, 23230-23234. [CrossRef]

44. Shi, H.; Zou, L.; Huang, K.; Wang, H.; Sun, C.; Wang, S.; Ma, H.; He, Y.; Wang, J.; Yu, H.-D.; et al. A Highly Efficient Red Metal-free Organic Phosphor for Time-Resolved Luminescence Imaging and Photodynamic Therapy. ACS Appl. Mater. Interfaces 2019, 11, 18103-18110. [CrossRef] [PubMed]

45. Gutierrez, G.D.; Sazama, G.T.; Wu, T.C.; Baldo, M.A.; Swager, T.M. Red Phosphorescence from Benzo[2,1,3]thiadiazoles at Room Temperature. J. Org. Chem. 2016, 81, 4789-4796. [CrossRef] [PubMed]

46. He, G.; Du, L.; Gong, Y.; Liu, Y.; Yu, C.; Wei, C.; Yuan, W.Z. Crystallization-Induced Red Phosphorescence and Grinding-Induced Blue-Shifted Emission of a Benzobis(1,2,5-thiadiazole)-Thiophene Conjugate. ACS Omega 2019, 4, 344-351. [CrossRef] [PubMed]

47. Zhu, Z.; Tian, D.; Gao, P.; Wang, K.; Li, Y.; Shu, X.; Zhu, J.; Zhao, Q. Cell-Penetrating Peptides Transport Noncovalently Linked Thermally Activated Delayed Fluorescence Nanoparticles for Time-Resolved Luminescence Imaging. J. Am. Chem. Soc. 2018, 140, 17484-17491. [CrossRef]

48. Mohanty, M.E.; Madhu, C.; Reddy, V.L.; Paramasivam, M.; Bangal, P.R.; Rao, V.J. Direct observation of the rise of delayed fluorescence in dithienylbenzothiadiazole and its role in the excited state dynamics of a donor-acceptor-donor molecule. Phys. Chem. Chem. Phys. 2017, 19, 9118-9127. [CrossRef]

49. Livshits, M.Y.; He, W.; Zhang, Z.; Qin, Y.; Rack, J.J. Triplet Excited-State Energetics and Dynamics in Molecular "Roller Wheels". J. Phys. Chem. C 2019, 123, 16556-16564. [CrossRef]

50. Goswami, S.; Winkel, R.W.; Schanze, K.S. Photophysics and Nonlinear Absorption of Gold(I) and Platinum(II) Donor-AcceptorDonor Chromophores. Inorg. Chem. 2015, 54, 10007-10014. [CrossRef]

51. Zhang, Y.; Chen, Z.; Wang, X.; He, J.; Wu, J.; Liu, H.; Song, J.; Qu, J.; Chan, W.T.-K.; Wong, W.-Y. Achieving NIR Emission for Donor-Acceptor Type Platinum(II) Complexes by Adjusting Coordination Position with Isomeric Ligands. Inorg. Chem. 2018, 57, 14208-14217. [CrossRef]

52. Chan, K.T.; Tong, G.S.M.; To, W.-P.; Yang, C.; Du, L.; Phillips, D.L.; Che, C.-M. The interplay between fluorescence and phosphorescence with luminescent gold(i) and gold(iii) complexes bearing heterocyclic arylacetylide ligands. Chem. Sci. 2016, 8, 2352-2364. [CrossRef] [PubMed]

53. Islam, S.N.; Sil, A.; Patra, S.K. Achieving yellow emission by varying the donor/acceptor units in rod-shaped fluorenyl-alkynyl based?-conjugated oligomers and their binuclear gold(i) alkynyl complexes. Dalton Trans. 2017, 46, 5918-5929. [CrossRef] [PubMed]

54. Chen, Q.; Liu, N.; Ying, L.; Yang, W.; Wu, H.; Xu, W.; Cao, Y. Novel white-light-emitting polyfluorenes with benzothiadiazole and Ir complex on the backbone. Polymer 2009, 50, 1430-1437. [CrossRef]

55. Sun, L.; Chen, Y.; Kuang, S.; Li, G.; Guan, R.; Liu, J.; Ji, L.; Chao, H. Iridium(III) Anthraquinone Complexes as Two-Photon Phosphorescence Probes for Mitochondria Imaging and Tracking under Hypoxia. Chem. A Eur. J. 2016, 22, 8955-8965. [CrossRef] [PubMed]

56. Smithen, D.A.; Monro, S.; Pinto, M.; Roque, J.; Diaz-Rodriguez, R.M.; Yin, H.; Cameron, C.G.; Thompson, A.; McFarland, S.A. Bis[pyrrolyl Ru(ii)] triads: A new class of photosensitizers for metal-organic photodynamic therapy. Chem. Sci. 2020, 11, 12047-12069. [CrossRef] [PubMed] 